\title{
Parameteres of mental health in childhood
}

\section{Параметри психічного здоров'я в дитинстві}

\author{
Elena Kazannikova
}

Олена Казаннікова

\author{
Herson State University, Herson, Ukraine \\ Херсонський державний університет
}

1. $\quad$ У сучасному суспільстві, де щороку посилюються вимоги до маленької особистості, проблема психічного здоров'я привертає увагу дослідників із різних галузей науки i практики. Аналіз становлення повноцінної особистості вказує на те, що часто деформації розвитку особистості беруть свій початок в дитинстві. Саме діти потребують уваги, оскільки соціально-політичні кризи суспільства завдають шкоди психічному здоров'ю підростаючого покоління.

2. Термін «психічне здоров'я» неоднозначний, і перш за все як би пов'язує дві галузі науки і практики - медичну і психологічну. Психічне здоров'я - елемент здоров'я в широкому сенсі. Здоров'я розглядають як багатомірний феномен, який має гетерогенну структуру, сполучає в собі якісно різні компоненти і відображає фундаментальні аспекти людського буття. Психічне здоров'я - це не просто відсутність недоліків, а й наявність ряду достоїнств у структурі особистості. Терміном здоров'я позначають стан повного душевного, фізичного і соціального благополуччя, а не тільки відсутність хвороб і фізичних дефектів [4].

3. Основними параметрами психічного здоров'я вважають:

4. 1. Пристосування до соціального і природного оточення можливість не тільки пристосуватися до існуючих умов, але й активно перетворювати їх.

5. 2. Нормальність - як відповідність соціальним і культурним нормам (соціокультурна характеристика здоров'я, загальна для представників даного соціуму).

6. 3. Стресостійкість і стабільність людини в процесі активної взаємодії з оточуючим світом.

7. 4. Гармонійна включеність у спільність людей, результатом чого є соціалізація дитини.

8. Психічне здоров'я можна визначати як відсутність виражених психічних розладів, як визначений резерв сил людини, завдяки якому вона може подолати неочікувані стреси. Психічне здоров'я - це сукупність установок, якостей і функціональних здібностей, які дозволяють індивіду адаптуватися до середовища [3].

9. $\quad$ Головний критерій оцінки психічного здоров'я, оптимального функціонування особистості - це характер і ступінь включеності індивіда у зовнішні біологічні і соціальні системи. 3 одного боку, мається на увазі такий рівень природних задатків людини, при якому забезпечується виживання i пристосування до оточуючого природного середовища. 3 іншого боку, мова 
іде про ступінь сформованості її соціальних стосунків та мірі відповідності їі поведінки основним нормам і вимогам соціуму. Психічне здоров'я свідчить про динамічну рівновагу індивіда 3 оточуючим середовищем, таке функціонування психіки індивіда, яке забезпечує йому гармонійну взаємодію зі світом. Психічне здоров'я людини характеризується іiі можливостями адаптації, соціалізації та індивідуалізації. Таким чином, психічне здоров'я, $є$ умовою адекватного виконання людиною своїх вікових i соціокультурних ролей, 3 іншого, забезпечує людині можливість безперервного розвитку протягом всього життя. Збереження фізичного i психічного здоров'я особистості, зокрема підростаючої - одне 3 най важливіших завдань суспільства i, насамперед, освіти [4].

10. Стан психічного здоров'я дитини пояснюється умовами іiі психосоціального розвитку. Основними показниками сформованості психічного здоров'я у дітей дошкільного віку є:

11. процес адаптації після вступу до ДНЗ;

12. рівень розвитку комунікативних навичок;

13. рівень позитивної мотивації до соціально важливої для даного віку діяльності;

14. відсутність відхилень у поведінці.

15. В ряді психологічних робіт психічне здоров'я співвідноситься з переживанням психологічного комфорту й психологічного дискомфорту. Будь-яка ситуація стає важкою, дискомфортною, коли виникає невідповідність між іiі основними елементами: потребами людини, iii можливостями та умовами діяльності. Дискомфортна ситуація завжди характеризується невідповідністю між чого людина прагне, і тим, що вона може, опинившись у даних обставинах. Така невідповідність перешкоджає досягненню поставленої мети, що детермінує виникнення негативних емоцій, які і є індикатором дискомфортної ситуації для людини. Існує дискомфорт і у дітей. Враховуючи таке розуміння дискомфортної ситуації, можна передбачити, що для розвитку дитини вони є типовими. Це зумовлено тим, що дитина пізнає та засвоює навколишній світ, але ще не володіє достатнім досвідом для розуміння невідомого, неочікуваного для неї, що обов'язково виникає в процесі пізнавальної діяльності. Це вимагає від неї випробування власних можливостей і здібностей, що не завжди може бути успішним i тому може стати приводом для розачарувань. Все це при визначених умовах може несприятливі наслідки для розвитку особистості дитини. Психологічний дискомфорт у дитини може виникнути в результаті фрустрацій iі потреб, що може зумовити психогенну дезадаптацію, депривацію. Фрустрація однієї чи декількох потреб дитини лежить в основі неврозів, які проявляються у вигляді різноманітних захворювань психосоматичного генезу. Дослідники відзначають, що найбільш суттєво впливають на дітей гострі психічні травми та хронічні психотравмуючи впливи, які $є$ ситуаціями підвищеного ризику і спричиняють виникнення дезадаптивних реакцій. Аналіз таких ситуацій, проведений спеціалістами, показує, що у дітей різного віку ці ситуації розрізняються за змістом. Для дошкільного віку найбільш характерними виявляються психотравмуючи ситуації, пов'язані із втратою (реальною чи уявною) почуття захищеності [2].

16. Порушення психічного здоров’я найчастіше спостерігається у 
дітей, які страждають від недостатнього спілкування 3 дорослими або їх ворожого ставлення, а також у дітей, які знаходяться в умовах сімейних розладів. Дитинство характеризується сильною емоційною прихильністю до батьків, особливо до матері, тому конфлікти між батьками, неадекватний стиль виховання, характер взаємостосунків у родині викликають у дітей постійне відчуття неспокою, невпевненості у собі, емоційне напруження i можуть стати джерелом психічного нездоров'я. Сильною психотравмуючою подією для дитини є розлучення з матір'ю, зумовлене іiі раннім виходом на роботу, це збільшує потребу дитини в ії прихильності і може спричинити фобії, негативізм, невротичні реакції. Означені ситуації, суттєво впливаючи на весь хід психічного розвитку, здатні порушити соціальну адаптацію дитини, деформувати ії психіку [1].

17. У психологічній літературі виділені і достатньо проаналізовані фактори, які впливають на психічне здоров'я дитини. Більшість 3 цих факторів носять соціально-психологічний, соціально-

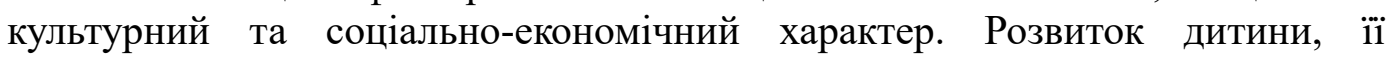
психічних й особистісних якостей багато в чому визначається тими взаємостосунками, які створюються між особистістю, що формується, i найближчим дорослим оточенням.

18.

19. Література:

20. Мамайчук I.I. Діти з розладами поведінки: психологічна допомога / I.I. Мамайчук. - К.: Редакції загально педагогічних газет, 2012. - 120c.

21. Проценко О.В. Профілактика соціальної дезадаптації дошкільнят / О.В. Проценко. - К.: Шкільний світ, 2011. - 128c.

22. Психологічне здоров'я дошкільників / Уклад. Т.І. Прищепа. - Основа, 2010. - 239c.

23. Терещенко Л.А. Як зберегти психічне здоров'я дітей 5-7 років / Л.А. Терещенко. -2012 . $-104 \mathrm{c}$ 